\title{
Veterans sue to force study
}

\section{Washington}

Two US veterans organizations last week filed suit to force the government to complete a study on the effects that exposure to Agent Orange had on Vietnam war veterans. Although the US Centres for Disease Control (CDC) abandoned the project after saying it could not be done, the two veterans organizations say that any refusal flaunts the explicit directions of Congress.

The two organizations - the American Legion and the Vietnam Veterans of America - say that government scientists were pressured to reject the study in 1987 because of fears that a link between exposure to the chemical defoliant Agent Orange, which contains dioxin, and cancer could leave the government open to lawsuits from private citizens.

The suit is based on a 1979 law mandating a federal study. CDC were assigned to do the work but in 1982, after a fouryear effort costing at least $\$ 43$ million, they concluded that existing service and Agent Orange spraying records were inadequate to determine how much dioxin each serviceman was exposed to. The White House later cancelled the study.

In April, the US Veterans Administration concluded that although no link between Agent Orange and cancer could be determined, Vietnam veterans stationed in areas that were not sprayed with the defoliant do appear to demonstrate a higher incidence of one particular form of cancer known as non-Hodgkin's lymphoma. It attributed the disease to an unspecified "Vietnam experience" and agreed to pay damages for such cases (Nature 343, 478; 5 April 1990).

But the veterans groups believe that a connection between Agent Orange and cancer does exist, something they say a well-conducted study would show. "We're saying the study can be done. It doesn't take a lot of brains to see that if you know where the Agent Orange was sprayed and you know where the troops were stationed, you can put the two together," says American Legion spokesman John Mimmick. The groups want a university or private contractor - but not $\mathrm{CDC}-$ to do the study.

Legal experts say that the veterans groups may find it difficult to win their case. Although private suits against the US government are not uncommon, victories are rare. Most cases fall down on an "issue of standing" - a legal provision requires a plaintiff to show that he or she was personally injured by the government's failure to satisfy its legal obligations. In the case of the Agent Orange study, the veterans groups will have to prove not only that the study was improperly halted, but that it would have demon- strated a cancer linkage if it had been allowed to continue, says Robert Kushen, a lawyer on the staff of Judge Jack Weintein. Weintein, a New York district judge who negotiated an $\$ 180$ million outof-court settlement between veterans and seven chemical companies that made Agent Orange in 1984.

Nevertheless, at least one congressman has already made his mind up on the matter. Representative Ted Weiss (Democrat, New York), last week released a statement on a soon-to-beWEST BERLIN ACADEMY

\section{Help from the East?}

\section{Munich}

THE West Berlin Academy of Sciences, a recent invention of the right-wing Christian Democrats, was pushed to the brink of collapse in Berlin last month when the Social Democrat-Green government passed a law dissolving it. In desperation, the academy is looking to its equally beleaguered neighbour, the East German Academy of Sciences, for help.

A conservative Christian Democratic government founded the West Berlin academy in 1987 in the face of strident objections from the Social Democrats (SPD), who were then in the opposition. The SPD criticized the academy as a "debating club" with decidedly conservative leanings which they would eliminate as soon as they were able.

But dissolving the academy has not proved as easy as the SPD had thought. It has taken 18 months for the disputed closing order to pass parliament, where it was reluctantly signed on 17 July by parliament president Jürgen Wohlrabe, a Christian Democrat.

Now, the West Berlin academy is preparing a legal challenge claiming that it may not be dissolved on purely political grounds. The case could set a precedent for the expected struggle over the East German academy, which many in the West would like to abolish. The Social Democratic science senator for West Berlin, Barbara Riedmüller-Seel, has said that a unified Berlin would have just one academy, and neither of the two existing ones would be a candidate.

Due to a quirk of West German law, the legal situation of the West Berlin academy is murky. The main argument of the academy - that the government may close a scientific institution only on scientific, not political, grounds - is based on a clause in the West German constitution (Grundgesetz). In any other Land, the case would pass out of local courts and move quickly to the highest court in West Germany, the Federal Constitutional conducted.

released staff report which finds that "CDC covered up the truth about Agent Orange by conducting a study that had been . . . intentionally designed to fail." It recommends that a new study should be

CDC spokeswoman Gayle Lloyd says the agency stands by its conclusions. And in an as yet unpublished letter to Time magazine criticizing a recent article on the subject, CDC director William Roper points out that the decision not to go ahead with the study had been reviewed and approved by Congress's own Office of Technology Assessment (OTA).

Christopher Anderson

Court at Karlsruhe.

But the high court has no jurisdiction over West Berlin, which despite the presence of numerous West German institutions remains a protectorate of the Allied powers. West Berlin is expected to become part of West Germany later this year when the German states are unified, but that may be too late for the academy.

At the very least, the West Berlin academy hopes the local court issues a stay of execution while the case (and the appeals that are sure to follow) is being heard. If not, the academy has until 31 December to pack up its tent and go.

In order to keep all options open, West Berlin academy president Horst Albach will this week discuss a possible merger with his counterpart from the East German academy, Horst Klinkmann of Rostock. Klinkmann is trying to save at least the learned society section of the East German Academy, originally founded by Leibniz in 1700 as the Prussian Academy of Sciences.

The former Communist government in East Germany made the academy the largest research organization in the country, with dozens of research institutions of its own, in addition to maintaining the learned society.

West Berlin academy spokesman Eberhard Vogt says that any proposed merger would certainly be fraught with problems. "A lot of our members would not want to cooperate" with the East German academy because of its Communist history, he says.

Before the collapse of the Communist regime in East Germany and the move towards unification, the West Berlin academy had hoped to move elsewhere in West Germany to avoid being disbanded (see Nature 342, 8; 1989). But the attempts failed and now "we can't leave Berlin", says Vogt, because the city will need help to deal with the economic and environmental challenges it now faces.

Steven Dickman 